\title{
Investigation of the Occupational Hygiene Errors in the Tasks of Overhead Crane Operator Using Standardized Plant Analysis Riskhuman Reliability Analysis Technique in One Steel Industry
}

\author{
Reza Jafari Nodoushan $^{1}$, Ali Sadri Esfahani², Tahmasb Akhtar², Khalil Taherzadeh Chenani ${ }^{*}$ i \\ 1 Dept of Occupational Health Engineering, School of Public Health, Shahid Sadoughi University of Medical Sciences, Yazd, Iran \\ 2 Dept of Industrial Engineering, Science and Arts University, Yazd, Iran
}

\begin{tabular}{l}
\hline Article Info \\
Article type: \\
Research article \\
\\
Article History: \\
Received: 30 May 2020 \\
Revised: 15 June 2020 \\
Accepted: 01 June 2021 \\
* Correspondence to: \\
Khalil Taherzadeh Chenani \\
Dept of Occupational Health \\
Engineering, School of Public \\
Health, Shahid Sadoughi \\
University of Medical Sciences, \\
Yazd, Iran \\
Email: khalil.oc.hy@gmail.com
\end{tabular}

A B S T R A C T

Introduction: Human error plays a significant role in the occurrence of industrial accidents. Displacement and unloading operations are operations in which the occurrence of human error may lead to plenty of human and financial losses. The present study aimed to investigate the possibility of human error occurrence in overhead crane operators in a Steel Company in Hormozgan, Iran.

Material \& Methods: This cross-sectional and descriptive study was conducted using the Standardized Plant Analysis Risk-Human Reliability Analysis (SPARH) technique. In this study, the job tasks of overhead crane operators were firstly analyzed using the hierarchical task analysis (HTA) technique. Subsequently, the probability of human error in job tasks was assessed using the SPAR-H technique. (Ethic code: IR.ACECR.JDM.REC.1399.005)

Findings: Generally, five main tasks and 16 sub-tasks have been analyzed in this study. The highest probability of error was related to the three sub-tasks of longitudinal motion, transverse motion, and high and low motion (0.3975). The lowest probability of error was under the duty of recording shift reports, transmitting information orally, and writing $(0.05)$. The results of this study clearly showed the effect of interdependence on increasing the probability of error occurrence.

Discussion \& Conclusion: Based on the results of the present study, some preventive measures were proposed to reduce the possibility of human error, including identifying and controlling job stressors, correcting the ergonomic status of crane cabins, preparing work instructions, as well as training and monitoring their proper implementation.

Keywords: HTA, Human error, Overhead crane, SPAR-H

$>$ How to cite this paper

Jafari Nodoushan R, Sadri Esfahani A, Kakai H, Akhtar T, Taherzadeh Chenani Kh. Investigation of the Occupational Hygiene Errors in the Tasks of Overhead Crane Operator Using Standardized Plant Analysis Risk-human Reliability Analysis Technique in One Steel Industry. November 2021;29(4): 8-17. 


\section{بررسى خطاهاى بهاشت شغلى در وظايف إيراتور جرثقيل سقفى، با استفاده از تكنيك واكاوى ريسك استاندار دشدهُ صنعتى در يك صنعت فولاد}

(iD)

رضا جعرى ندوشن' (ID) ، على صدرى اصفهانى"، طهماسب اختر'، خليل طاهرزاده جنانى "

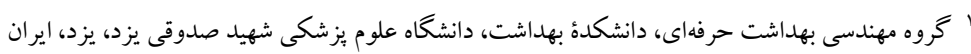

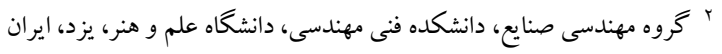

مقدمه: خطاهاى انسانى نقش فراوانى در بروز حوادث صنعتى دارند. عمليات جابجايى و تخلية جرثقيلى بار از عملياتهايى نوع مقاله: يزوهشى

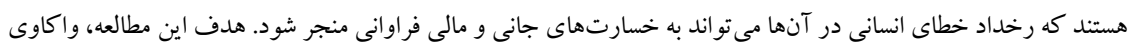

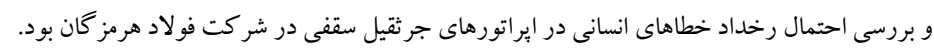

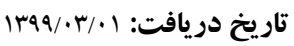
تاريخ داورى: مواد و روش ها: اين يزوهش مقطعى و توصيفى با استفاده از تكنيك SPAR-H صورت يـذيرفت. در ايسن مطالعسه، ابتـدا

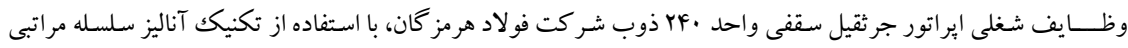

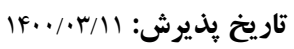

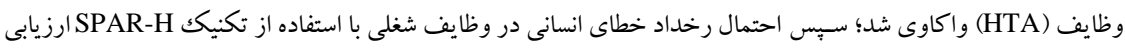
كرديد. يافته ها: درمجموع، ه وظيفه اصلى و 19 زير وظيفة وارد واكاوى شـد. بيشترين احتمال رخداد خطا مربوط به سه زير وظيفة

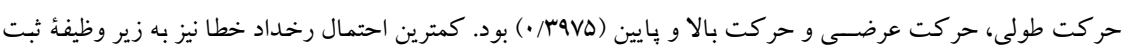

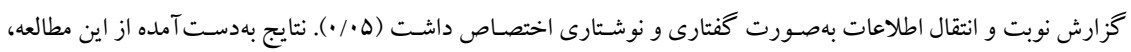
بهروشنى تأثير وابستخى ميان وظايف را در افزايش احتمال رخداد خطا نشان مىدهد. بحث و نتيجه كيرى: نتايج مطالعه حاضـر نشـان مىدهد كه بهمنظور كاهش احتمال رخداد خطاى انسـانى، شـناسـايى و

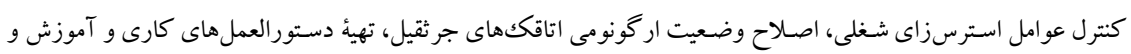
نظارت بر اجرا و به كار گيرى درست آنها ضرورى به نظر مىرسد.

$$
\text { نويسنده مسئول: }
$$
خليل طاهرزاده جنانى كروه مهندسى بهداشت حرفهاى، دانشكدة بهداشت، دانشگاه علوم يزشكى شهيد صدوقى يزد، يزد،

Email:

khalil.oc.hy@gmail.com

$$
\text { وازههاى كليدى: خطاى انسانى،HTA SPAR-H، جرثقيل سقفى }
$$

> > استناد: جعفرى ندوشن، رضا؛ صدرى اصفهانى، على؛ اختر، طهماسب؛ طاهرزاده جنانى، خليل. بررسى خطاهاى بهداشت شغلى در وظايف اير اتور

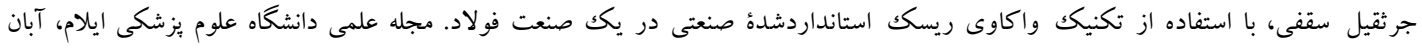
$\Lambda-I V:(F) Y q ! I F .$. 
تشخيصى و عملكردى بر آورد كرد (A). اين تكنيك، تو صيفى از وظايف برحسب عمليات، يعنى فعاليتهايى كه كاربر براى دستيابى به اهداف سيستم انجام مىدهد و طرح كار، يعنى جّكونكى و ترتيب اجراى هريك از عمليات بالا در مرحلة بعد و در يكك سطح يايينتر است. اين سلسلهمراتب تا جايى كه تحليلكر تشخيص دهد، ادامه مىيابد (9). از اين روش در صنايع و مشاغل مختلفى مانند بررسى احتمال رخداد خطاى انسانى در سامانهُ مجوز كارى (يرميت) در يكك صنعت بتروشيمى ( •(1)، بررسى احتمال رخداد خطا در بخش اورزانس زايمان (11)، ارزيابى خطاى انسانى در حرفهُ يرستارى بخش مراقبتهاى ويزٔه قلب (r) و ارزيابى قابليت اطمينان انسانى در فرايند دياليز (1) (1) استفادهشده است.

در روش SPAR-H، تحليل گر مفاهيم مرتبط با رويدادهاى نقص انسانى را با استفاده از عوامل شكل دهندهُ عملكرد (PSFs) موجود در كاربر گهاى مجزا براى فعاليتهاى تشخيصى، عملكردى و تشخيصىعملكردى محاسبه مى كند. عو امل يادشده مشتمل بر هشت مورد است كه هريكك از اين عوامل، خود سطوحى با ضرايب مختص به خود دارند و بر اساس ضرايب اين سطوح و فرمولهاى موجود، احتمال رخداد خطا در وظايف تشخيصى، عملكردى و تشخيصى -عملكردى محاسبه مى شود (F) (I). با عنايت به مطالب يادشده و ماهيت حساس كار جرثقيلهاى سقفى كه يك اشتباه كوجنك مىتواند به خسارتهاى جبراننايذير منجر شود و و همجنين گستردگى به كار گيرى اين تجهيزات در صنايع متفاوت، شناسايى انواع خطاهاى احتمالى، ارزيابى و ارائهُ راهكارهاى مناسب بهمنظور كاهش ريسك رخداد اين گونه خطاها، يكك ضرورت انكارنايذير بهشمار مىرود. مطالعهُ حاضر با هدف شناسايى، ارزيابى و مديريت خطاهاى انسانى در اير اتورهاى جرثقيل سقفى در يكك صنعت فلزى در استان هرمز كان، با استفاده از تكنيك SPAR-H صورت يذيرفت.
در دنياى توسعهيافتهُ امروز، حوادث بهعنوان يكى از مهم ترين مشكلات شناخته مىشوند. آمار حوادث نشان مىدهد كه عامل بيش از •ه درصد از حوادث صنعتى، بهطور مستقيم يا غيرمستقيم، به خطاهاى انسانى مرتبط است (1). بررسى حوادث بزرگك و فاجعهبارى مانند فليكس بورو، انفجار در نيرو كاه اتمى ترى مايل آيلند، حادثٔ

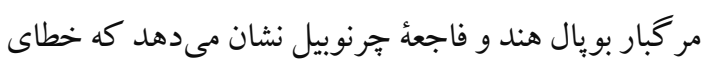
انسانى در بروز اين حوادث نقش اساسى داشته است (Y-Y). خطاى انسانى بهعنوان شكست ناخواسته در انجام فعاليتهاى هدفمند و برنامهريزىشده در دستيابى به نتيجهاى مطلوب تعريف مى شود (ه).

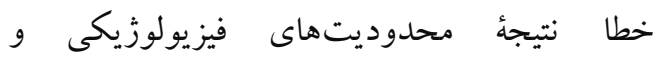
روانشناختى انسان است و بهطور قابلتوجهى بيجيده

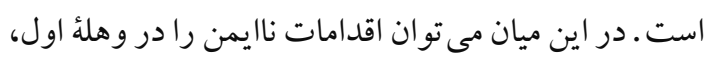
ناشى از فرايندهاى ذهنى نابجا مانند فراموشى، غفلت، بع توجهى، انخيزهُ ضعيف، بـدقتى و بى بروايى دانست

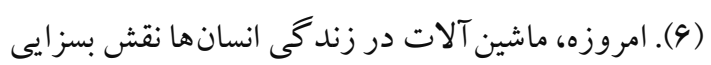
دارند و بيشرفت در صنايع بدون به كار گيرى ماشين آلات،

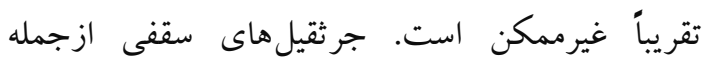
ماشين آلاتى هستند كه بهطور كستردهاى در صنايع براى انتقال بارهاى سنخين استفاده مى شوند. اين ماشين آلات از سوى انسان اداره مى گردند و اشتباهات فردى مى تواند به اله حوادث جبراننايذيرى منجر شود. ايمنى در كار با جر ثقيل ها همواره مورد بحث و نخخرانى بسيارى از محققان بوده و بر جنبه هاى متفاوتى از كار با جرثقيل ها به تحقيق

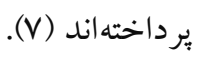
روش SPAR-H يكى از روشهاى ارزيابى احتمال خطاى انسانى است كه براى طبقهبندى و كمىسازى سهم انسان در خطا به كار مىرود. اين روش بهمنظور ارزيابىهاى ريسك احتمالى توسعهيافته است كه با استفاده از آن مى توان احتمال رخداد خطاهاى انسانى را در فعاليتهاى تشخيصى، عملكردى و يا تشخيصى -عملكردى بر اساس تعديل ضرايب احتمال رخداد خطاى اسمى براى وظايف 
سلسلهمراتبى وظايف يكى از روشهاى واكاوى وظايف شغلى است كه معمولاً در فرايند ارزيابى قابليت اطمينان و اين مطالعهُ مقطعى و توصيفى، با هدف شاد شناسايى و شناسايى خطاهاى انسانى كاربرد دارد. در اين روش، ارزيابى احتمال رخداد خطاى انسانى در عمليات حمل بار

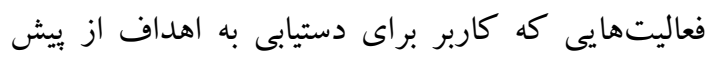

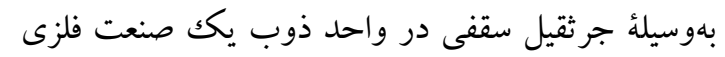

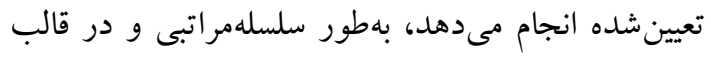
جارت يا جدول تجزيهو تحليل مىشوند (1) (1). در استان هرمز گان انجام شد. در اين صنعت، 19 إيراتور جرثقيل سقفى در جهار

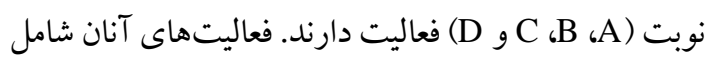
تعويض و تحويل نوبت، بازرسى ييش از شروع به كار، بلند

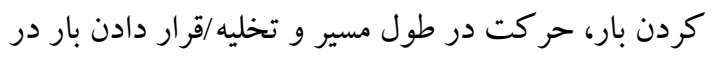
محل مدنظر است. انسانى به كار مىرود. در اين روش، هشت عامل

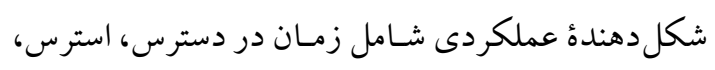

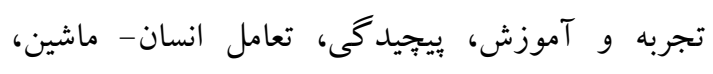

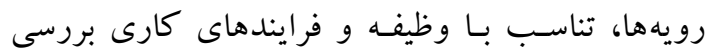
مطالعة رويههاى كارى و مصاحبه با كاركنان صورت

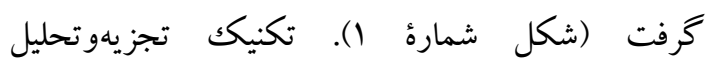

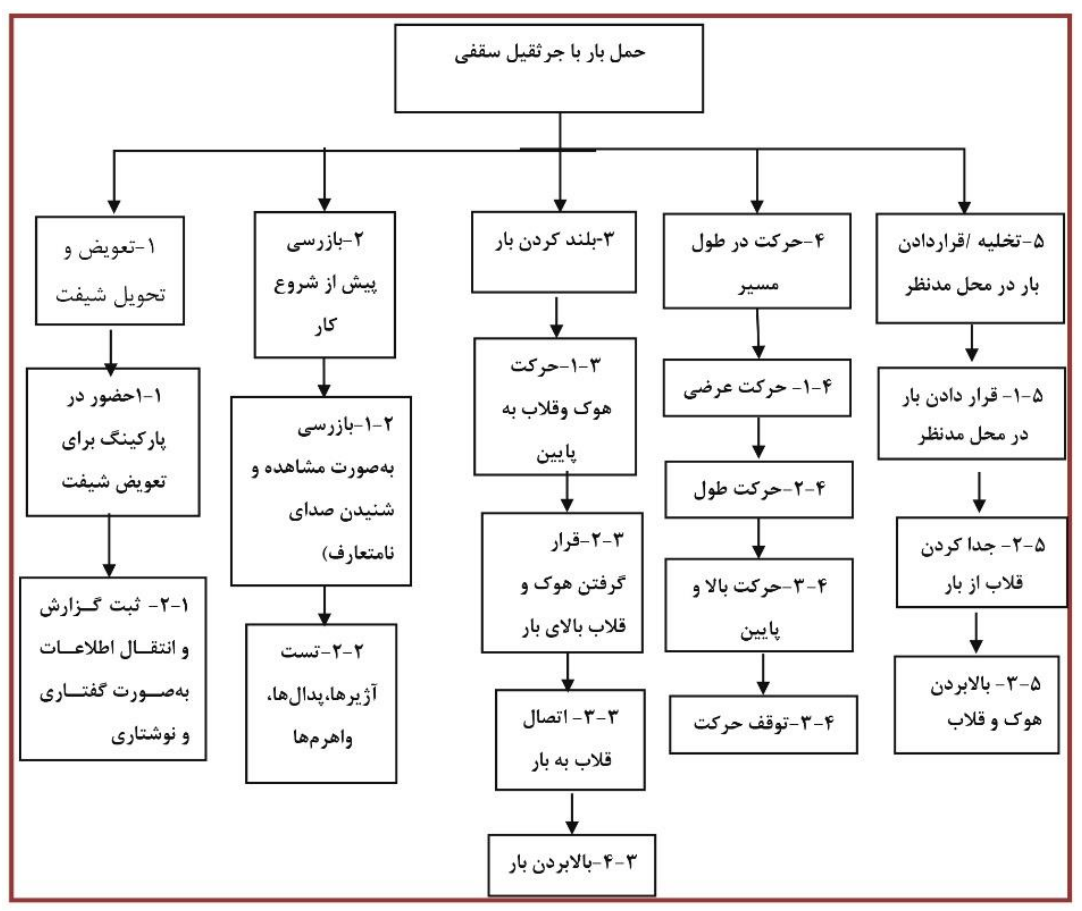

شكل ا. دياگرام HTA براى إيراتور جرثقيل سقفى

تشخيصى شامل تفسير و تصميم گيرى است و بر دانش و مراحل اجراى مطالعه تجربة فردى براى دركى شرايط موجود، برنامهريزى، مرحلــة اول اولويتبندى فعاليتها و تعيين عملكردهـاى مناسب اتكا تجزيهوتحليل وظـايف شغلى (تشخيصى، عملكردى

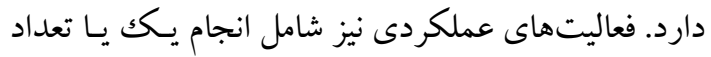

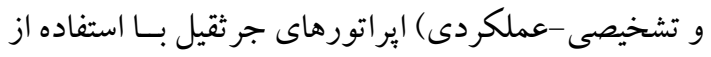
بيشترى فعاليت است كه بهوسيلة تشخيص، قوانين روش تجزيهوتحليل سلسـلهمراتبى وظايف: وظايف 
اسـترس و عوامل استرسزا × يِيجيد كى × آموزش /تجربه × روش هاى عملياتى × ارگونومى/HMI × تناسب با وظيفه

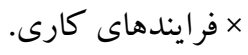

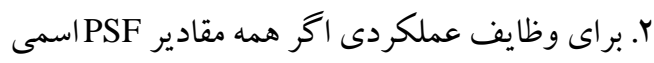
باشـند، احتمـال خطا برابر با | +. / و در غير اين صورت، احتمال رخداد خطا براى وظايف عملكردى مطابق رابطة ب محاسبه مى شود. رابطو r. احتمال خطاى وظايف عملكردى؛ احتمال خطا براى وظايف تشخيصى: 1 +•• × زمان در دسترس × اسـترس و عوامل استرسزا × يِيجيدكى × آموزش /تجربه × روش هاى عملياتى × ارگونومى/HMI × تناسب با وظيفه

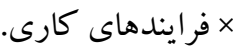

". محاسبة عامل تنظيمى. زمانى كه سه مورد و يـا بيشتر از عوامل شكلدهنده عملكرد ضريب بالاى يك داشته باشند، بهجاى معادلات بـالا، از معادلات ديخرى استفاده مىشود. احتمال خطاى اسمى بر اي وظايف تشخيصى 1 • • و براى وظايف عملكردى ا +•• در راهنماى روش SPAR-H در نظر كرفتهشده است. مقدار PSF تر كيبى كه در ايـن حالت استفاده مى گردد، حاصل ضرب (PSFc) همــُ مقـادير تعيينشده عوامل شكلدهندهُ عملكردى است؛ ازاينرو، براى احتمال رخداد خطاى انسانى در وظايف با بيش از سه عامل منفى (عوامل با ضريب بالاى يكك)، در وظايف تشخيصى و عملكردى، بهترتيب از روابط ب و F استفاده مى شود. گفتنى است كه احتمال رخداد خطا براى وظايف تشخيصى-عملكردى، از طريق جمع احتمال رخداد خطا براى هريك از وظايف تشخيصى و عملكردى حاصل مى گردد (If).

$$
\begin{aligned}
& H E P D=\frac{0.01 \times P S F_{C}}{0.01\left(P S F_{C}-1\right)+1} \\
& H E P_{A}=\frac{0.001 \times P S F_{C}}{0.001\left(P S F_{C}-1\right)+1}
\end{aligned}
$$

ج. محاسبئ احتمال خطاى وظيفـه بـدون وابستسكى (Pw/od)

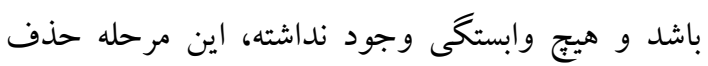

عملكردى و يا دستور العملها تعيين شدند. كار با يدالها، واكنش در برابر يكك آلارم و غيره نمونههايى از وظايف عملكردى هستند. وظايف تشخيصى -عملكردى شامل هر دو جنبة وظايف تشخيصى و عملكردى است (If). با توجه به تعداد بالاى وظايف و زير وظايف، براى تعيـين اصلىترين و بحرانىترين وظـايف إيراتورها در كار با جرثقيل هاى سقفى، گروه بارش افكار شامل سرشيفتها، اير اتورها و نفر ات باتجربة تعميرات جرثقيل در محيط انجام يزوهش تشكيل گرديد و برخطرترين آنها براى ارزيابى احتمال رخداد خطاى انسانى وارد مطالعه شدند. مرحلة دوم در اين كام، احتمال خطاى انسانى براى زير وظايف روم شغلى محاسبه گرديد. ايسن مرحله از مطالعه در قالب كامهاى زير صورت گرفت: الف. ارزيابـى تأثير هـريـك /ز عو/مل شكل دهندئ عملكــرد /ز بعل تشخيصى يا عملكردى: در اين مرحله،

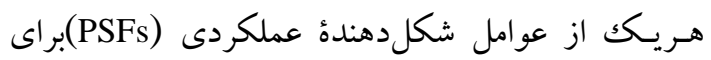
وظايف تشخيصى يا عملكردى در وظايف مدنظر ارزيابى شد. هريكك از اين عوامل سـوح متفاوتى بـا ضرايب خاص خود دارند. تعيين ضريب هريـك از عوامل شكل دهندهُ عملكرد در كاربر گكهاى مربوط به فعاليتهاى تشخيصى يا عملكردى، ابتدا بـا استفاده از روشهاى

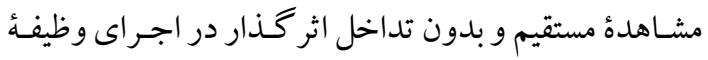
روتسين ايراتورها، از سوى فرد بزوهشگ و سيس از طريق مصاحبه با سرشفيت ها و إيراتورهاى داراى سابقه كارى بالا يا تعمير كاران باتجربه مشتص كرديد. ب. محاسئ احتمال رخداد خطا در وظايف لهيف شناسايىشله؛ ا. براى وظايف تشخيصى اكر همهٔ مقادير PSF كر فته مى شود، در غير اين صورت، احتمال رخداد خطا براى وظايف تشخيصى مطابق با رابطهُ ا محاسبه مى شود. رابطه 1. احتمال خطاى وظايف تشخيصى؛احتمال خطا براى وظايف تشخيصى: 1 •/ × زمان در دسترس × 
فرد اســت. در اينجا، منظور از وابســــى، اثر منفى يكك مى كردد. خطاى انسانى بر خطاهاى بعدى است كــــه در احتمـــــال د. تعيين ميز/ن و/بسـتحى موجسـود ميان وظايف: از جدول خطاى كلى محاســبه مىشــود. وابســتِى مى تواند در شمارهُ ا براى شـــرايط وابســــى استفادهشده است كــهـ

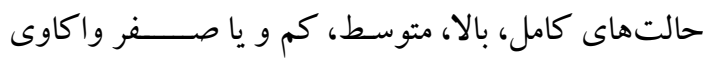

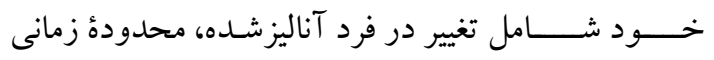

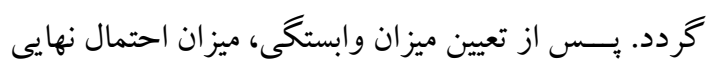
نزديكك و يا دور، تغييسر كردن يا نكردن مكان انجاموظيفه احتمال رخداد خطـا محاسـبه مىشود (IV). و وجــــود داشتن يا نداشتن نشانههاى اضافى براى هدايت

جدول 1. سطوح وابستخى و معادلات محاسبة آنها

\begin{tabular}{|c|c|c|c|c|c|c|}
\hline رابطةٌ احتمال خطاى انسانى & وابستغى سطح & 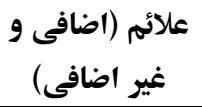 & محل انجاموظيفه & (نزديك / بافاصله زمانى & 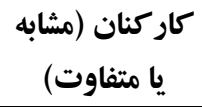 & رديف \\
\hline احتمال خطا=1 & كامل & با بدون نشانهُ اضافى & مشابه & نزديكك & & 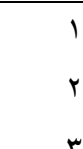 \\
\hline$\underline{\left(1+P_{W} / O D\right)}$ & بالا & با باون نشانهُ اضافى & متفاوت & & & $\begin{array}{l}r \\
r\end{array}$ \\
\hline $\begin{array}{c}2 \\
\left(1+6 \times P_{W} / O D\right)\end{array}$ & متوسط & بدان بان نشانهُ اضافى & مشابه & & مشابه & $\begin{array}{l}0 \\
4\end{array}$ \\
\hline $\begin{array}{c}\frac{7}{\left(1+19 \times P_{W} / O D\right)} \\
\frac{20}{20}\end{array}$ & متوسط & بدان بان بانه اضافى اضافى & متفاوت & بافاصله & & $\mathrm{v}$ \\
\hline$\underline{\left(1+6 \times P_{W} / O D\right)}$ & متوسط & با باون نشانهُ اضافى & مشابه & نزديكك & & $\begin{array}{l}9 \\
1 .\end{array}$ \\
\hline 7 & متوسط & بدا بدون نشأهُ اضافى اضافى & متفاوت & & متفاوت & $\begin{array}{l}11 \\
14 \\
14\end{array}$ \\
\hline$\frac{\left(1+19 \times P_{W} / O D\right)}{20}$ & צإِيين & با با بان بانئ اضافى نشأُ اضافى اضافى & متفاوت & بافاصله & & $\begin{array}{l}14 \\
10 \\
19\end{array}$ \\
\hline $\begin{array}{c}\text { احتمال شكست برابر } \\
P_{W} / O D\end{array}$ & & & لخعى صفر & & & IV \\
\hline
\end{tabular}

وظيفه آنها براى ارزيابى احتمال رخداد خطاى انسانى در

كافته ها انجام آنها وارد مطالعه شدند. در مطالعهُ فعلى، ابر اتورهاى جرثقيل · YF. واحد ذوب يافته هاى حاصل از ارزيابى و آناليز به روش SPAR-H بررسى شدند. بررسى فعاليتهاى إيراتورهاى جرثقيل در جدول شماره ب نشان دادهشدهاند. بيشترين احتمال خطا سقفى و وظايف شغلى آنان با استفاده از تكنيكك بدون محاسبة ضريب وابستكى، مربوط به وظايف سلسلهمراتبى آناليز وظايف صورت گرفت (شكل شماره (). درنهايت، ه وظيفه اصلى (تعويض و تحويل نوبت، حركتهاى عرضى، طولى و بالا و يايين آوردن بار بازرسى ييش از شروع به كار، بلند كردن بار، حر كت در ثبت گزارش نوبت و انتقال اطلاعات بهصورت كنتارى و و طول مسير و تخليه/قرار دادن بار در محل مدنظر ) و 19 زير 
جدول r. ميزان احتمال رخداد خطا در فعاليتهاى جرثقيلهاى .rF واحد ذوب

\begin{tabular}{|c|c|c|c|c|c|}
\hline \multirow[t]{2}{*}{ خطاى كل احتمال } & \multirow[t]{2}{*}{ 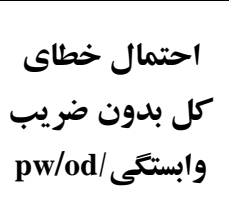 } & \multicolumn{2}{|c|}{ 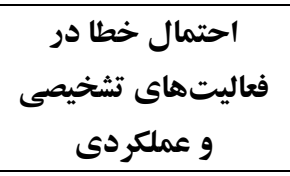 } & \multirow[b]{2}{*}{ زير وظايف } & \multirow{2}{*}{ بخشها } \\
\hline & & عملكردى & تشخيصى & & \\
\hline.$/ 194$ &.$/ 10 \cdot 0$ & $.11 \cdot .9$ & .1 .499 & حضور در پيار كينگ براى تعويض نوبت & \multirow[b]{2}{*}{ تعويض و تحويل نوبت } \\
\hline$\cdot / \cdot \Delta$ & $.1 \cdots 9$ &.$/ \cdots 9$ & - & ثبت گزارش نوبت و انتقال اطلاعات & \\
\hline.$/ 194$ & $\cdot / 10 \cdot 0$ & $\cdot 11 \cdot .9$ & .1 .499 & مشاهدة اجزا & \multirow{2}{*}{ كازرسى ييش از شروع به } \\
\hline$\cdot /$ TFIV & $\cdot / r \cdot 1 \Lambda$ & $\cdot 11 \cdot \cdot 9$ & $\cdot 11 \cdot \cdot 9$ & تست آزيرها، سلكتورها، بِدالها و اهرمها & \\
\hline - MFIV & $\cdot / 4 \cdot 11$ & $\cdot 11 \cdots 9$ & $\cdot 11 \cdots 9$ & حركت هوكك و قلاب به بايين & \multirow{4}{*}{ بلند كردن بار } \\
\hline$\cdot /$ MFIV & $\cdot / r \cdot 1 \Lambda$ & $\cdot 11 \cdot .9$ & $\cdot 11 \cdot .9$ & قرار گرفتن هو كك و قلاب بالاى بار & \\
\hline - MFIV & $\cdot / 4 \cdot 1 \Lambda$ & $\cdot 11 \cdots 9$ & $\cdot 11 \cdots 9$ & اتصال قلاب به بار & \\
\hline - ITFIV & $\cdot / 4 \cdot 11$ & $\cdot 11 \cdots 9$ & $\cdot 11 \cdots 9$ & بالا بردن بار & \\
\hline$\cdot /$ rqvo & $\cdot / M 9 \Delta \Lambda$ & $\cdot /$ /Arq & $\cdot / M A Y q$ & حر كت عرضى & \multirow{4}{*}{ حر كت در طول مسير } \\
\hline$\cdot /$ rqvo & $\cdot / 49 \Delta \Lambda$ & $\cdot / M \Lambda r$ & $\cdot / M A Y q$ & حر كت طول & \\
\hline$\cdot /$ rqvo & $\cdot / 49 \Delta \wedge$ & $\cdot / \Lambda \wedge r q$ & $\cdot / M A Y q$ & حركت بالا و يايين & \\
\hline -IYFIV & $\cdot / 4 \cdot 11$ & $\cdot 11 \cdots 9$ & $\cdot 11 \cdots 9$ & توقف حركت & \\
\hline . MFIV & $\cdot / 4 \cdot 11$ & $\cdot 11 \cdot .9$ & $\cdot 11 \cdots 9$ & حركت هوكت و قلاب به بايين & \multirow{4}{*}{ تخليه/قرار دادن بار در } \\
\hline$\cdot$ ITFIV & $\cdot / 4 \cdot 1 \Lambda$ & $\cdot 11 \cdots 9$ & $\cdot 11 \cdots 9$ & قرار دادن بار در محل مدنظر & \\
\hline - IMFIV & $\cdot / 4 \cdot 11$ & $\cdot 11 \cdots 9$ & $\cdot 11 \cdots 9$ & جدا كردن قلاب از بار & \\
\hline - MFIV & $\cdot / r \cdot 11$ & $\cdot 11 \cdot .9$ & $\cdot 11 \cdots 9$ & بالا بردن هو كك و قلاب & \\
\hline
\end{tabular}

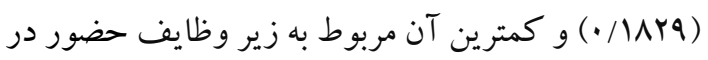

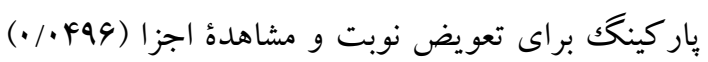
مربوط مىشود. در بعد عملكردى نيز بيشترين احتمال رخداد خطا مربوط به حر كتهاى طولى، عرضى و بالا و بايين (1/1/99 •) است. كمترين احتمال رخداد خطا در بعد عملكردى نيز به زير وظيفه ثبت گزارش نوبت و انتقال اطلاعات بهصورت كفتارى و نوشتارى (9 . ٪•) مربوط مى شود.

\section{بحث و نتيجه تيرى}

اين مطالعه با هدف ارزيابى احتمال رخداد خطاى انسانى در فعاليتهاى جابجايى بار بهوسيلة جرثقيل سقفى در يكك صنعت فلزى صورت گرفت. بلند كردن بار،
نوشتارى (q (./.) بود. با در نظر گرفتن وابستگى نيز، بيشترين احتمال خطا مربوط به حر كتهاى عرضى، طولى

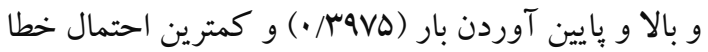
مربوط به وظيفه ثبت گزارش نوبت و انتقال اطلاعات

$$
\text { بهصورت كفتارى و نوشتارى (ه •/•) است. }
$$

با توجه به جدول شماره ب، زير وظايف حركتهاى عرضى، طولى و بالا و بايين آوردن بار با احتمال رخداد

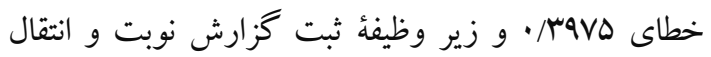
اطلاعات بلصورت گفتارى و نوشتارى با احتمال خطاى ه•••• بهترتيب بيشترين و كمترين احتمال رخداد خطا را دارند.

در بعد تشخصى، بيشترين احتمال رخداد خطا به حركتهاى عرضى، طولى و بالا و بِيين آوردن بار 
مهم ترين عوامل مؤثر بر رخداد خطا يادشده است ( r).

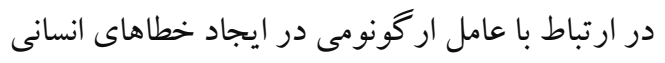
در جرثقيلهاى سقفى، مغايرتهايى از قبيل يوسجر

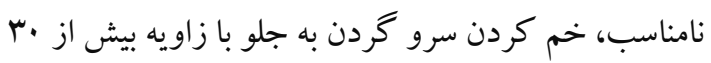
درجه، طراحى نامناسب صندلىها، لرزش و ارتعاشات

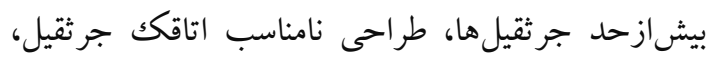

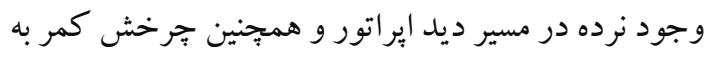
سبب وجود نقاط كور در زمان باربردارى مشاهده گرديد.

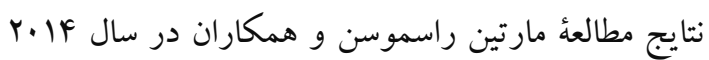

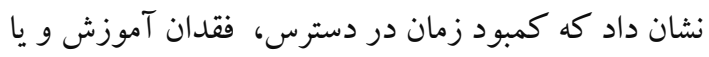
تجربه و ضعف تعامل ميان انسان و ماشين از عوامل دمال دمان

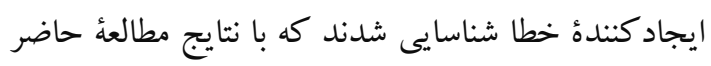

$$
\text { همخوانى دارد (Y) (Y). }
$$

در مطالعهُ قلعهنوعى و همكاران، مهم ترين عو امل مؤثر

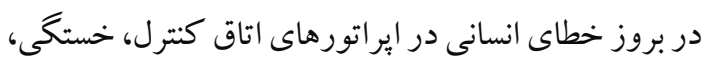
كمبود تجربه، هوشيارى، بيجيد

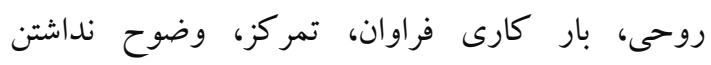

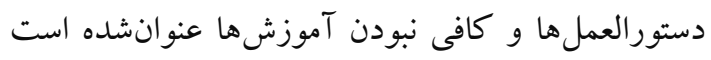

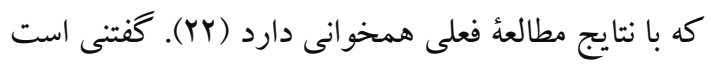

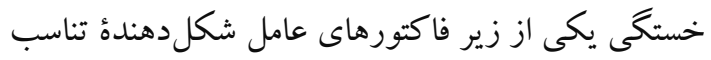

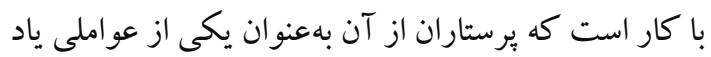

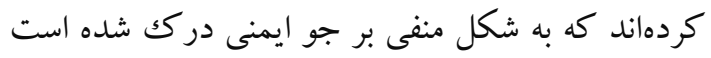

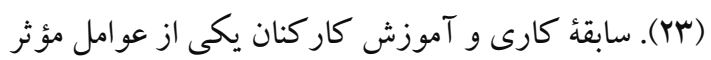

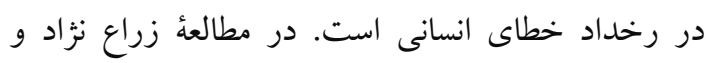

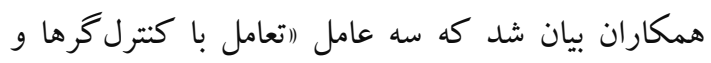
نشانكرها)، (ادستور العمل ها)، و (آموزش و تجربهابها)، به تنهايى

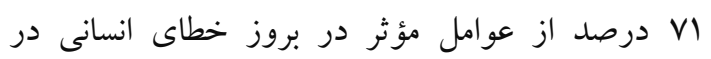
ايراتورهاى اتاق كنترل را به خود اختصاص دادهاند (YF).

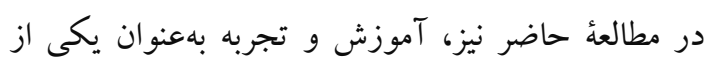
عو امل مؤثر بر بروز خطا در وظايف شغلى شناسايى شد.

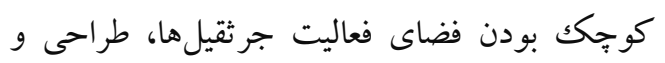
جيدمان نامناسب دستخاهها و قرار گيرى نامناسب تجهيزات

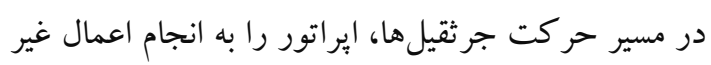

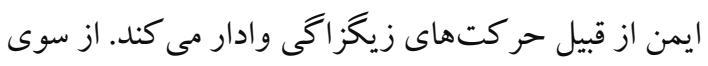

حركت در مسير و تخليه/قرار دادن بار در محل مدنظر

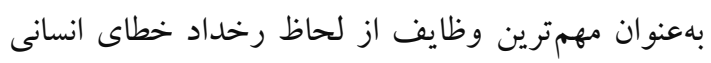
شناسايى شدند. عامل رويههاى كارى يكى از عوامل شكلددهندة

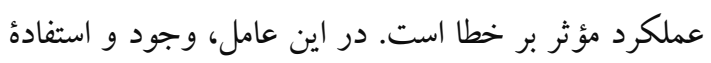
درست از دستور العمل ها و رويههاى كارى رسمى بر ايى انجام وظايف شغلى مدنظر قرار مى گيرد. در اين مطالعه، اين عامل

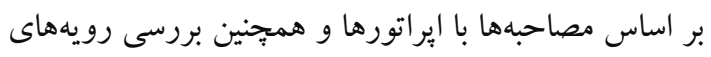

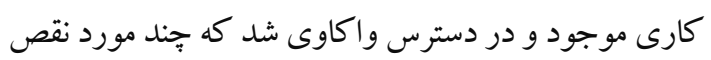

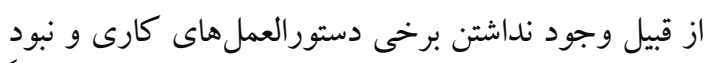
آموزش صحيح به كارگيرى برخى ديخر مشاهدهشده است.

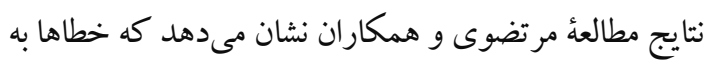
علت در دسترس نبودن دستورالعملهاى مكتوب و و يا فيان

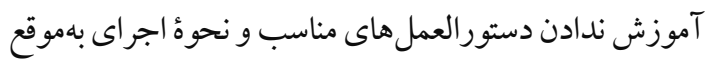

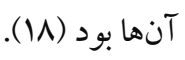
در مطالعهاى كه عيوضلو و همكاران در ارتباط با يكك

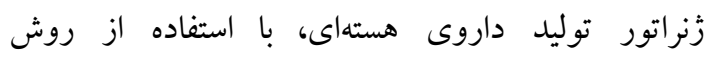
SPAR-H انجام دادند، ميانخين احتمال خطا بس/، بر آورد

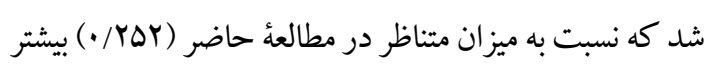

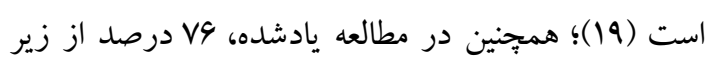
وظايف سطح بالايى از استرس و .9 درصد از آنها سطح بالايى از بيجيجيدى داشتند كه اين امر مىتواند نشان از از

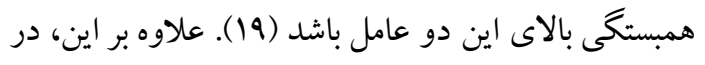

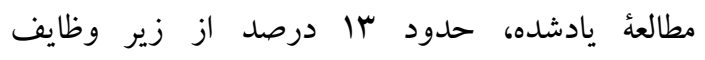

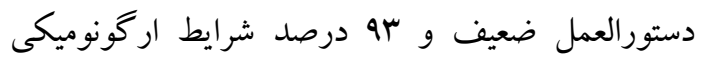

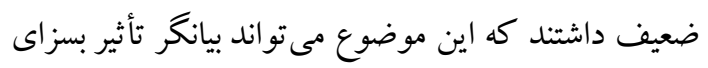
اين دو عامل بر افزايش احتمال رخداد خطاى انسانى باشد ماتد (19). در مطالعهاى كه على آبادى و همكاران انجام دادند،

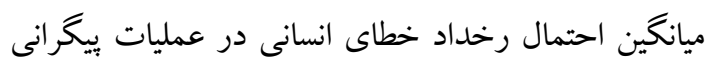
معادل / /Y/ • بر آورد شد كه نسبت به ميزان متناظر در مطالعة فعلى، كمتر است. اين اختلاف مىتواند ناشى از متفاوت

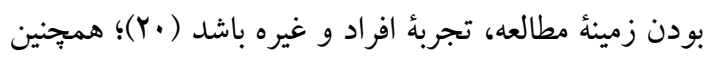

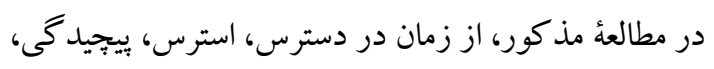

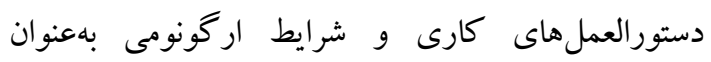




$$
\begin{aligned}
& \text { تهيئ دسـتور العمل هاى كارى مناسـبـ و كامل، آموزش و } \\
& \text { نظارت بر اجراى درسـت دســور العمل ها، نصـبـ علائم } \\
& \text { هشـداردهنده و همجزنين در صسورت لزوم، طراحى مجدد } \\
& \text { اتاقك رادر بيش بكيرند. }
\end{aligned}
$$$$
\text { تشكر و قدردانى }
$$$$
\text { در بِيان، از همكارى مديريت محترم مجتمع فولاد }
$$$$
\text { هرمز گان و مسئولان نوبتها و ابراتورهاى جرثقيلهاى }
$$$$
\text { سقفى تقدير و تشكر مى گردد. اين مقاله بر گرفته از }
$$$$
\text { ياياننامهُ مصوب با عنوان (ارزيابى خطاى انسانى در }
$$$$
\text { ابراتورهاى جرثقيل سقفى با استفاده از روش واكاوى }
$$$$
\text { ريسك استانداردشدهُ صنعتى SPAR-H در شركت فولاد }
$$$$
\text { هرمز گان جنوب)، است. }
$$

\section{تعارض منافع}

نويسند كان اعلام مى كنند كه تضاد منافعى در اين

$$
\text { مطالعه وجود ندارد. }
$$

\section{كد اخلاق: IR.ACECR.JDM.REC.1399.005}

\section{References}

1. Hollnagel EJC. Control. Hum Reliabil Analy 1993;2:123-6.

2. Donaldson MS, Corrigan JM, Kohn LT. To err is human building a safer health system. $1^{\text {th }}$ ed. National Acad Publication. 2000;P.49-82.

3. Lees F. Lees loss prevention in the process industries hazard identification assessment and control. $4^{\text {th }}$ ed. Butterworth Heinemann Elsevier Publication.2012; P.131-203.

4. Evangeliou N, Balkanski Y, Cozic A, Hao W, Mouillot F, Thonicke K, et al. Fire evolution in the radioactive forests of Ukraine and Belarus future risks for the population and the environment. Ecol Monogr 2015;85:49-72. doi.10.1890/14-1227.1

5. Karwowski W. Accident analysis and human error international encyclopedia of ergonomics and human factors volume set. $1^{\text {th }}$ ed. CRC Publication. 2006; P.1937-40.

6. Dhillon BS. Human reliability error and human factors in engineering maintenance. $1^{\text {th }}$ ed. Taylor Franc Publication.2009. P.1-10.

7. Mandal S, Singh K, Behera R, Sahu S, Raj N, Maiti JJESWA. Human error identification and risk prioritization in overhead crane operations using hta and sherpa and fuzzy Vikor method. Exp Syst Appl 2015;42:7195-206. doi.10.1016/j.eswa.2015.05.033

8. Walsh T, Beatty PCJPm. Human factors error and
ديخر، مشكلاتى مانند غيراستاندارد و خراب بودن صندلىهاى ايراتور جرثقيلها، اختلال در دستكاههاى

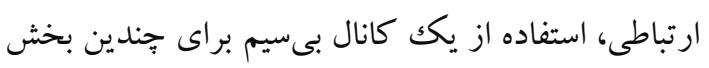
و عمل نكردن و خرابى سيستم آنتى كلوزن (سيستم ترمز هوشمند) مى تواند ييامدهايى مانند سقوط ياتيل مذاب، سقوط تانديش، شل، سقوط اسلب و غيره را به همر اه داشته باشد. سقوط بِاتيل خالى از مواد مذاب، سقوط اسلب و سقوط الكترود جند نمونه از حوادثى هستند كه علت رخداد آنها مى تواند مربوط به خطاى انسانى باشد.

در اين بثزوهش مى توان علل عمدهُ خطاهاى انسـانى را

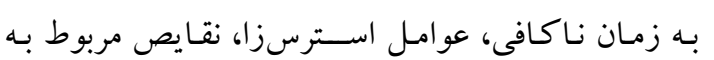

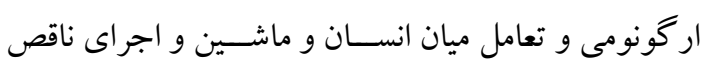
دسـتور العمل ها نسـبت داد. در بايان بيشــنهاد مى شــود كه

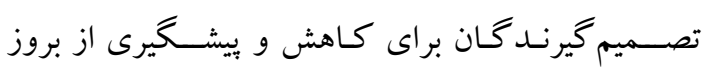
خطاهاى انسـانى در جرثقيل هاى سـالن ذوب، اقداماتى از قبيل كاهش شــدت اثر عو امل اســترسزا مانـد صـــدا و ارتعاش جرثقيلها، بررسى كارايى دستخاههاى روشنايى و

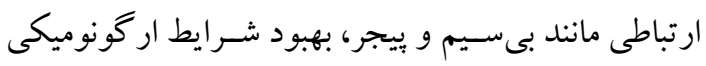

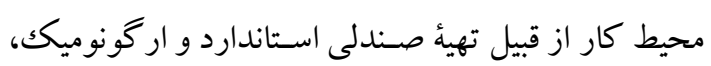

patient monitoring. Physiol Measure2002;23:111-32.

9. Stanton NA. Hierarchical task analysis developments applications and extensions. Appl Ergon2006;1;37:55-79.

doi.10.1016/j.apergo.2005.06.003

10. Jahangiri M, Hoboubi N, Rostamabadi A, Keshavarzi S, Hosseini AA. Human error analysis in a permit to work system a case study in a chemical plant. Saf Health Work2016;7:6-11. doi.10.1016/j.shaw.2015.06.002

11. Tanha F, Mazloumi A, Faraji V, Kazemi Z, Shoghi MJJoH. [Evaluation of human errors using standardized plant analysis risk human reliability analysis technique among delivery emergency nurses in a hospital affiliated to Tehran University of medical sciences]. J Hospital 2015;14:57-66. (Persian)

12. Mohammadfam I, Movafagh M, Soltanian A, Salavati M, Bashirian S. Assessment of human errors in the nursing profession of intensive cardiac care unit using Spar H method]. Occup Med2015; 7: 10-22. (Persian)

13. Rasekh RJIJoE. [Evaluation of human reliability by standardized plant analysis risk Spar $\mathrm{H}$ method in the dialysis process in ebne sina hospital Shiraz]. Iranian J Ergon2019;7: 44-56. (Persian)

14. Gertman D, Blackman H, Marble J, Byers J, Smith 
C. The Spar H human reliability analysis method. US Nucle Regul Com 2005;230:35.

15. Diaper D, Stanton N. The handbook of task analysis for human computer interaction. $2^{\text {th }} \mathrm{ed}$. CRC Publication. 2003;P.1-30.

16. Blackman HS, Gertman DI, Boring RL. Human error quantification using performance shaping factors in the Spar $\mathrm{H}$ method. Proce Hum Fact Ergon Soc Meet 2008; 52: 1697. doi.10.1177/154193120805202109

17. Gertman D, Blackman H, Marble J, Byers J, Smith CJUNRC. The spar $\mathrm{H}$ human reliability analysis method. Am Nuclear Soc Int Top Meet Nucle Plant Ins Cont Hum 2005;230:35.

18. Mortazavi S, Mahdavi S, Asilian H, Arghami S, Gholamnia R. [Identification and assessment of human errors in srp unit of control room of tehran oil refinery using heist technique]. J Kermanshah Uni Med Sci 2008; 12: 308-322. (Persian)

19. Eyvazlou M, Dadashpourahangar A, Rahimi A, Davarpanah MR, Sayyahi SS, Mohebali MJjoos, et al. Human reliability assessment in a 99Mo $99 \mathrm{mTc}$ generator production facility using the standardized plant analysis risk human Spar H technique. Int J Occup Saf Ergon2019;25:321-30. doi. 10.1080/10803548.2017.1415832
20. Aliabadi MM, Esmaeili R, Mohammadfam I, Ashrafi M. Application of a standardized plant analysis risk human reliability method to pipeline inspection gauge operations. J Occup Hyg Eng 2019;6:34-43.

21. VandeMerwe K, Hogenboom S, Rasmussen M, Laumann K, Gould KJSE, Management. Human reliability analysis for the petroleum industry lessons learned from applying Spar H. SPE Econ Manag2014;6:159-64. doi.10.2118/168470-PA

22. Ghalenoei M, Asilian H, Mortazavi S, Varmazyar S. [Human erroranalysis among petrochemical plant control room operators with human errorassessment and reduction technique]. Iran Occup Health J2009;6:38-50. (Persian)

23. Khamma A, Poursadeghiyan M, Marioryad H. Patient safety climate and its affecting factors among rehabilitation health care staff of hospitals and rehabilitation centers in Iran Tehran. Iranian Rehabil J 2019;17:39-47. doi.10.32598/irj.17.1.39

24. Zarrnezhad A, Jabbari M, Keshavarzi MJIOH. [Identification of the human errors in control room operators by application of HEIST method case study in an oil company]. Iran Occup Health 2013;10: 11-23. (Persian) 